\title{
Reproductive behavior in riverside women: health survey in an isolated community in the Middle Solimões, Amazonas, Brazil
}

\author{
Comportamento reprodutivo em mulheres ribeirinhas: inquérito de \\ saúde em uma comunidade isolada do Médio Solimões, Amazonas, \\ Brasil
}

Ivone Cabra|1, Wilsandrei Cella', Silvia Regina Freitas'
1 Universidade do Estado do Amazonas (UEA) - Tefé (AM), Brasil. silvia.sampaio.freitas@ hotmail.com
DOI: $10.1590 / 0103-11042020127091$

\begin{abstract}
Health surveys conducted in geographically isolated communities help to characterize reproductive behavior and its conditioning factors. The aim of this study was to know the sexual and reproductive health profile and the socio-cultural and economic aspects related to riverside women from Middle Solimões, Amazonas, Brazil. This is a retrospective and descriptive study carried out with women from Vila Sião community, Alvarães (AM). Twenty-eight women, 18-57 years old, were individually interviewed using a survey form to obtain socio-cultural data, sexual and reproductive life histories. The results of the descriptive analyses indicated that the respondents were of mixed race, with elementary education, married and worked in family-based agriculture. Regarding the respondents' sexual life history, it was noted that the relationships are long-lasting, with the same partner, and that the first pregnancy occurred during adolescence. Gestational indicators showed a predominance of home birth. These women had a high fertility coefficient. However, the history of gestational loss attributed to eclampsia, home accidents, and illnesses emphasizes the importance of prenatal care for the promotion of the pregnant woman and the baby. From these results it is concluded that the internalization of health services is essential for specialized medical assistance to reach the riverside and isolated communities of Amazonas, Brazil.
\end{abstract}

KEYWORDS Health surveys. Reproductive health. Rural population.

RESUMO Os inquéritos de saúde conduzidos em comunidades geograficamente isoladas auxiliam na caracterização do comportamento reprodutivo e seus condicionantes. O objetivo deste estudo foi conhecer o perfil da saúde sexual, reprodutiva e aspectos socioculturais e econômicos de mulheres ribeirinhas do Médio Solimões, Amazonas, Brasil. Estudo retrospectivo e descritivo feito com mulheres da comunidade da Vila Sião, Alvarães (AM). No total, 28 mulheres, com idades entre 18 e 57 anos, foram individualmente entrevistadas, utilizando formulário para a obtenção de dados socioculturais, históricos de vida sexual e reprodutiva. Os resultados das análises descritivas indicaram que as entrevistadas eram mestiças, com ensino fundamental, casadas e atuavam na agricultura familiar. Em relação à história de vida sexual das entrevistadas, notou-se que os relacionamentos eram duradouros, com os mesmos parceiros, e as primeiras gestações ocorreram ainda na adolescência. Os indicadores gestacionais mostraram predomínio de parto domiciliar. Essas mulheres apresentaram elevado coeficiente de fecundidade. No entanto, os históricos de perdas gestacionais atribuídos à eclâmpsia, a acidentes domésticos e a doenças enfatizam a importância do acompanhamento pré-natal para a promoção da saúde da gestante e do bebê. A partir desses resultados, conclui-se que a interiorização dos serviços de saúde é essencial para que uma assistência médica especializada chegue até as comunidades ribeirinhas e isoladas do Amazonas, Brasil.

PALAVRAS-CHAVE Inquéritos epidemiológicos. Saúde reprodutiva. População rural. 


\section{Introduction}

Since the mid-twentieth century, the reproductive behavior of Brazilian women has gone through changes that have led their fertility coefficient to decline significantly' ${ }^{1}$. This phenomenon reflects contemporary behavioral and social changes in which factors such as unrestricted access to all levels of educational training ${ }^{2,3}$, increasing participation in the labor market ${ }^{4}$, financial independence ${ }^{5}$, as well as the advent of contraceptive methods ${ }^{6}$ have given women greater control over their reproductive dispositions and options regarding the number of pregnancies and the length of time between one and other pregnancy.

However, in contrast to the national scenario, women living in isolated regions have reproductive behavior compatible with that observed at the beginning of the last century ${ }^{7}$. That is, in these communities there is still sexual precocity, a high level of fertility and a short time between pregnancies ${ }^{8,9}$. In general, this reproductive pattern is associated with indicators of low socioeconomic development such as subsistence activities, low education and limited access to public and health services $^{\mathbf{1 0 , 1 1}}$. In the state of Amazonas, isolated communities are found in rural regions, on the banks of lakes and rivers, and distant up to $500 \mathrm{~km}$ from urban centers ${ }^{\mathbf{1 2}}$. The geographical isolation resulting from the long distance from urban centers and the proximity to the forest favor subsistence economic activities such as fishing, extraction and family farming ${ }^{13,14}$. In addition, Amazonian riverside communities do not have regular essential public services offered to them. Therefore in order to access health services, centralized at municipal headquarters, riverside residents are subject to displacements that can last for days or weeks ${ }^{12,15}$.
The economic, social and cultural peculiarities of the riverside populations located in the state of Amazonas contribute to the failure of programs aimed at women's health ${ }^{16,17}$. Therefore, it is essential to consider such specificities in order to develop and/or improve strategies to promote these initiatives ${ }^{\mathbf{1 8}, 19}$. To this end, it is necessary to carry out surveys aimed at this target audience, in order to provide input to public policies aligned with the culture and reproductive profile of women living in Amazonian communities. In this sense, the present study aimed to know the profile of the sexual and reproductive health and the social, cultural and economic aspects of the riverside women in the municipality of Alvarães, Middle Solimões region, Amazonas state, Brazil.

\section{Material and methods}

This retrospective and descriptive study was conducted in July 2019 with adult women and residents of Vila Sião, Alvarães (AM) (picture 1). Although this community is part of the municipality of Alvarães (AM), the nearest urban center is in the municipality of Tefé (AM), $40 \mathrm{~km}$ away by river ${ }^{20}$.

Local businesses are modest and have only basic products for food (rice, pasta, oil, sugar, salt), cleaning (washing powder, bar soap, chlorine, steel wool) and personal hygiene (soap, toothpaste and toothbrush, disposable diaper, toilet paper).

There are no pharmacies, bakeries, markets or banking institutions in the locations. Fundamental public services (health post and basic sanitation) are not offered either. Electricity is irregular and comes from a small thermal power plant. 
Picture 1. Front view of Vila Sião, Alvarães (AM).

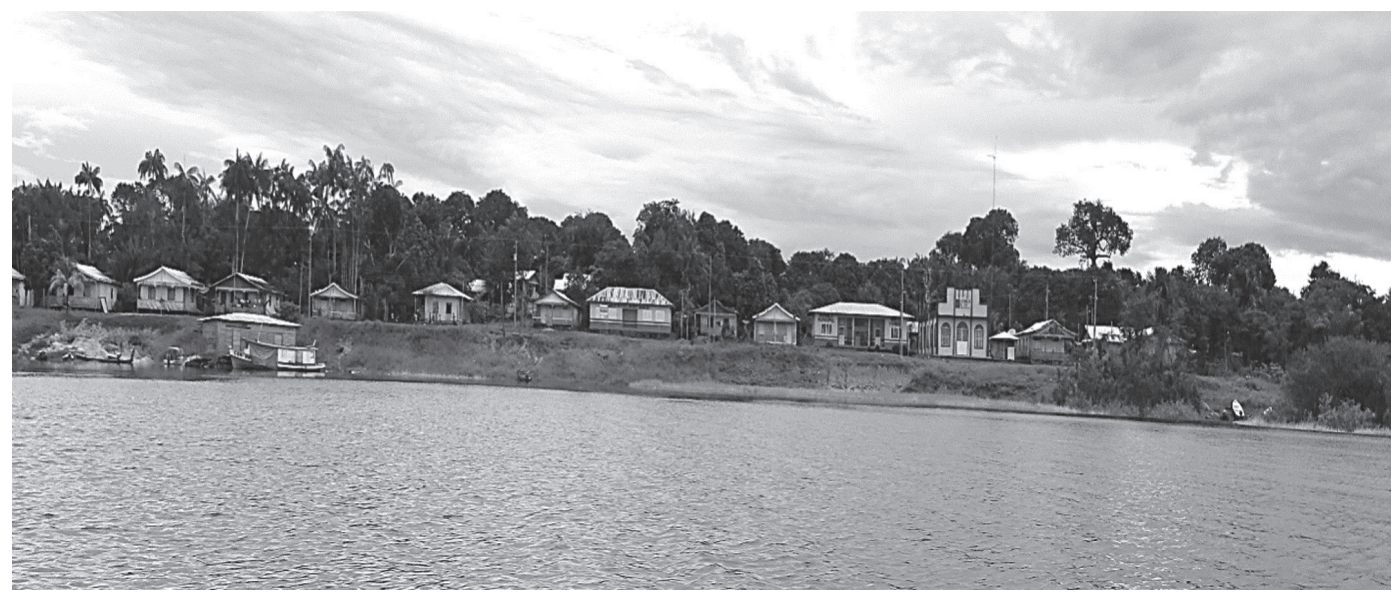

Source: Image taken by Ivone Ketura Silva Cabral, on August 10th 2019.

The community has approximately 230 inhabitants, organized into 44 families, and is one of the most populous of the one hundred riverside communities located in the National Forest of Tefé20,21. The region's residents have family farming as their means of subsistence, with an emphasis on the production and commercialization of manioc flour, artisanal fishing and the extraction of andiroba, açaí, chestnut and copaíba. Now and then hunting activities are carried out ${ }^{\mathbf{2 2}}$.

For the selection of participants, the parameters considered were as follows: being 18 years old or older, having started sexual life and having a history of pregnancy. Women who did not meet any of these parameters were excluded from the study.

Interviews were conducted by a single researcher and carried out at the participants' homes, where a semi-structured survey form was applied to obtain sociodemographic, sexual life and reproductive health information.

Sociodemographic information included age, marital status (single, married/stable, separated/divorced), self-declared ethnicity (mixed race, Negro, Caucasian), religion, education level (illiterate, primary school, high school) and economic activity. To outline the profile of their sexual life, the evaluation encompassed their time of relationship with the current partner ( $<10$ years; $\geq 10$ years), their number of sexual partners and their use of contraceptive methods. In the analysis of reproductive health, both maternal conditions (age of menarche, age of first pregnancy) and conditions of pregnancy (total number of pregnancies, number of completed pregnancies, number of interrupted pregnancies, gestational diseases, prenatal care, number of prenatal examinations, type of delivery [cesarean section or normal], gestational age [preterm, term]) were investigated.

The information obtained throughout the interviews was organized and tabulated in a spreadsheet with restricted access to the researchers involved in this study. With the aid of the statistical program EpiInfo (version 3.5.1), it was possible to carry out descriptive analyses. Qualitative variables were expressed in absolute and relative numbers.

This research respected the ethical and scientific standards established by Resolution No. 466, of December 12, 2012, of the National Health Council/Ministry of Health. Its protocol was approved by the Research Ethics Committee of the University of the State of Amazonas, through 
the Opinion No. 2,895,249, of July 15, 2018.

All participants were made aware of the objectives of the study and of the confidentiality of the information provided. After accepting the invitation to participate in the study, they all signed the Free and Informed Consent Form.

\section{Result and discussion}

In total, $28(87.5 \%)$ adult women with ages ranging from 18 to 57 were interviewed. Four women were excluded from the study: three of them were not in the community in the period of the interviews and one of them was not lucid enough to be interviewed given her old age.

\section{Sociodemographic and economic profile of riverside women in Vila Sião, Alvarães (AM)}

The sociodemographic analysis (table 1) shows respondents are predominantly of mixed race ( $\mathrm{n}=16 ; 57.1 \%)$; with ages between 20 and 33 years $(\mathrm{n}=12 ; 42.9 \%)$; with completed primary school $(\mathrm{n}=22 ; 78.6 \%)$; are married or in a stable relationship $(n=26$; 92.6\%); and are evangelical ( $\mathrm{n}=16 ; 57.1 \%)$. Most of the respondents ( $\mathrm{n}=20 ; 71.4 \%$ ) have been living in the community for more than 10 years.

In general, women in the area are young and in a stable relationship. Illiteracy cases are restricted to women over 40 and probably related to those who did not benefit from the recent creation of a primary school unit in the community. In recent years, investment in teacher training courses such as the National Primary Education Teacher Training Program (Parfor), associated with the construction of new schools, has contributed to taking primary education to the hinterland and to the establishment of teachers in isolated communities of the state of Amazonas ${ }^{\mathbf{1 2}}$. Therefore, it is understood that this new social scenario is already reflected in the expressive number of women with complete primary education.

Table 1. Sociodemographic profise of adult women residente in Vila Sião, Alvarães (AM), 2019

\begin{tabular}{lrr}
\hline Variables & Number of people & Percentage (\%) \\
\hline Ethnicity & 16 & \\
\hline Mixed race & $37.1 \%$ \\
Negroid & 9 & $10.7 \%$ \\
Caucasian & & $32.1 \%$ \\
\hline Current age & 7 & $25 \%$ \\
\hline$<20$ years & 12 & $42.9 \%$ \\
$20-33$ years & 9 & $32.1 \%$ \\
\hline 35 years & & $10.7 \%$ \\
\hline Education Level & 3 & $78.6 \%$ \\
\hline Illiterate & 22 & $10.7 \%$ \\
Primary school & 3 & $3.6 \%$ \\
High school & & $92.6 \%$ \\
\hline Marital status & 1 & $3.6 \%$ \\
\hline Married & 26 & 1 \\
\hline
\end{tabular}


Table 1. (cont.)

\begin{tabular}{lrr}
\hline Variables & Number of people & Percentage (\%) \\
\hline Religious profile & 4 & \\
\hline Catholic & 16 & $14.3 \%$ \\
Evangelical & 8 & $57.1 \%$ \\
No religion & & $28.5 \%$ \\
\hline Time residing in the community & 7 & $25 \%$ \\
\hline$<10$ years & 20 & $71.4 \%$ \\
$>10$ years & 1 & $3.6 \%$ \\
Does not remember & & $35.7 \%$ \\
Economic profile & 10 & $25 \%$ \\
\hline No income & 7 & $10.7 \%$ \\
1 minimum wage & 3 & $28.6 \%$ \\
\hline Was not willing to answer & 8 & \\
\hline
\end{tabular}

Source: Own elaboration

The predominant economic activities among the riverside women in the community are family farming - based on planting greens, vegetables and manioc - and the marketing of flour. Hunting and artisanal fishing activities are restricted to men in the community. Most of the women interviewed state that they have no fixed monthly income $(\mathrm{n}=10$; $35.7 \%$ ). The justification reported is that family income is obtained exclusively through the sale of manioc flour in the urban centers of Tefé (AM) or Alvarães (AM). Therefore, during the months of manioc planting and harvesting and of flour production, survival comes from hunting, fishing and from what the land might give, such as fruits and vegetables. Among those who have a monthly income, the earnings come from a regular pension ( 1 minimum wage: $\mathrm{n}=$ $3 ; 10.7 \%$ ) or from public social assistance (less than 1 minimum wage: $\mathrm{n}=7 ; 25 \%$ ).

Insufficient family income is widely found in riverside communities in the state of Amazonas ${ }^{\mathbf{1 2}, 22,23}$. But despite economic limitations, the abundance of food obtained from local rivers and from the forest seems to meet the nutritional needs of the respondents and their families.

\section{Sexual life history and contraceptive practices}

When investigating the history of the active sexual life of women from Vila Sião, Alvarães (AM), one can notice that relationships are long lasting - over 10 years $(n=15 ; 54 \%)$ - and that many remain with the same partners ( $\mathrm{n}$ $=21 ; 75 \%$ ) (table 2). This behavior is different from that seen both among indigenous peoples $^{\mathbf{2 4}}$ and in urban populations ${ }^{\mathbf{2 4}}$. In this sense, an early initiated and long lasting marital union, without change of partners, presents itself as a cultural and prevalent behavior in some riverside and isolated communities in the state of Amazonas ${ }^{6}$.

Although the women interviewed are in socially stable relationships, the majority of them declare having no intention to become pregnant $(\mathrm{n}=20 ; 71.4 \%)$. This option is presented by the respondents regardless of how many children they already have. For this reason, $92.8 \%(n=26)$ adopts some type of contraceptive strategy. Contraceptives mentioned by most women were oral $(n=4$; $14.3 \%)$ and injectable $(n=4 ; 14.3 \%)$ hormonal contraceptives and the male condom $(n=3$; 
10.7\%). However, adherence to such practices is subject to the availability of these devices for the community of Vila Sião, Alvarães (AM). The community's only health post is inoperative. As a consequence, women there only have access to commercial contraceptives when being visited by agents of the Family Health Program, or, more seldom, when travelling to the urban centers of Tefé (AM) or Alvarães (AM). Oral/injectable contraceptives and barrier methods (male/female condoms) are essential to birth control, as well as to the prevention of sexually transmitted infections ${ }^{26}$. However, the irregular supply of these devices, due to logistical limitations, compromises the efficient control of conception and of possible sexual infections among the women of Vila Sião, Alvarães (AM).

As an alternative to conventional methods of contraception, $28.6 \%(n=8)$ of the respondents regularly use homemade teas. Native herbal teas are a recognized practice among women who are either indigenous ${ }^{\mathbf{2 4}}$ or from isolated Amazonian communities, ${ }^{\mathbf{1} 27}$. Among the native herbs mentioned by the respondents, the following stand out: saracura-mirá, carapanaúba, sara-tudo, boldo, cotton and copaiba. Biochemical and pharmacological studies conducted on the plant extracts mentioned by the respondents show the presence of molecules with contraceptive action ${ }^{28-30}$. Knowing the traditional practices of conception control such as the use of teas based on natural herbs is a differential of health professionals who work in isolated communities. This professional qualification enables the integration of cultural knowledge with medical practices of body care, configuring a feasible strategy for the promotion of the sexual health of riverside women.

Among those who do not use contraceptive methods, $25 \%(\mathrm{n}=7)$ reported having undergone tubal ligation. The choice of this method of contraception belonged to the women themselves, with the purpose of having smaller families. They claim that sterilization is the most efficient measure for reproductive control, considering the irregularity of access to traditional contraceptive methods (male condom, oral/injectable contraceptives).

In this study, the percentage of women who do not use any type of contraceptive method is of $7.1 \%(n=2)$. The size of the offspring reflects a social behavior reported in other isolated populations in the Middle Solimões region, Amazonas, Brazil6,24,31. In these cases, prenatal care becomes essential to provide guidance on what should be a minimum interval between pregnancies. According to the Guidelines of the Brazilian Society of Gynecology and Obstetrics, women should wait for 18 months between pregnancies in order to ensure that future pregnancies will have an adequate development ${ }^{32}$.

Based on the parameters investigated, it is suggested that the women of Vila Sião, Alvarães (AM), are in a process of socio-cultural transition that favors a family structure with less children. However, to confirm this hypothesis, it is necessary to carry out follow-up studies, as well as to monitor future generations.

Table 2. Profile of sex life of adult women residente in Vila Sião, Alvarães (AM), 2019

\begin{tabular}{lrr}
\hline Variables & Number of people & Percentage (\%) \\
\hline Time of relationship & & \\
\hline$<10$ years & 13 & $46 \%$ \\
$\geq 10$ years & 15 & $54 \%$ \\
\hline
\end{tabular}




\begin{tabular}{lrr} 
Table 2. (cont.) & Number of people & Percentage (\%) \\
\hline Variables & & \\
\hline Number of Partners & 21 & $75 \%$ \\
\hline Only 1 Partner & 7 & $25 \%$ \\
$>1$ Partner & & $28.6 \%$ \\
\hline Intenção de Engravidar & 8 & $71.4 \%$ \\
\hline Yes & 20 & $39.3 \%$ \\
No & & $28.6 \%$ \\
\hline Use of contraceptive methods & 11 & $25 \%$ \\
\hline Conventional methods & 8 & $7.1 \%$ \\
Homemade methods & 7 & 2 \\
Female sterilization & & \\
No use of contraceptives & & \\
\hline
\end{tabular}

Source: Own elaboration.

\section{Reproductive health and its maternal and gestation indicators}

The menarche of the respondents came when they were between 11 and 13 years old $(\mathrm{n}=26 ; 92.9 \%)$, as shown in table 3 . This parameter agrees with that of the Consensus of the Brazilian Federation of Gynecology and Obstetrics Associations ${ }^{32}$. According to this document, the first menstruation occurs between 10 and 16 years of age, with an average age of 12.3 years. Therefore, the menarche is conditioned to an improvement in women's living and health conditions ${ }^{32}$.

The first pregnancy occurred most frequently when they were between 14 and 15 years of age $(\mathrm{n}=19 ; 67.9 \%)$. When adding the age groups of $14-15$ years and $16-17$ years, it is observed that $78.6 \%$ of women started their reproductive cycle while still in adolescence. This tendency to concentrate fertility in the youngest ages of the reproductive period is frequently observed in vulnerable groups, whose average ages for the first pregnancy range from 16 to $17^{33}$. It is clear that early pregnancy can bring risks both to the mother's and the baby's health, as a consequence of the functional immaturity of an adolescent's body ${ }^{34}$. In order to minimize the adverse effects of early pregnancy, studies point to the adoption of reproductive education measures. That is, actions aiming to educate and clarify about puberty, hormonal changes, menstrual cycle, contraceptive methods, fertilization and pregnancy ${ }^{34,35}$. In fact, the specialized literature already shows successful results from reproductive education programs conducted both in schools $^{36,37}$ and in basic health units ${ }^{34}$. In view of the various reports of success, it becomes relevant to include reproductive education as a cross-cutting theme in primary schools, as well as to create health programs with an emphasis on this theme. However, the format of reproductive education must consider the cultural and local specificities of the target audience; in this case, the riverside and isolated communities of the Middle Solimões region, Amazonas, Brazil. 
Table 3. Maternal indicators inclued in the analysis of the reproductive profile of adult women residing in Vila Sião, Alvarães (AM), 2019

\begin{tabular}{lrr}
\hline Maternal indicators & Number of people & Percentage $\%$ \\
\hline Age of menarche & & \\
\hline Between 11 and 13 years & 26 & $92.9 \%$ \\
Between 14 and 15 years & 2 & $7.1 \%$ \\
\hline Age at first pregnancy & & $67.9 \%$ \\
\hline 14 to 15 years & 19 & $10.7 \%$ \\
16 to 17 years & 3 & $21.4 \%$ \\
\hline
\end{tabular}

Source: Own elaboration.

When evaluating gestational indicators (table 4), there was a predominance of vaginal delivery at the home of the parturient and with the help of midwives ( $n=17 ; 61 \%)$. In the community mentioned before, only pregnant women at enough risk to justify cesarean delivery are referred to hospital services available in the urban centers of Tefé (AM) or Alvarães (AM), resorting to hospital delivery.

In Brazil, the mode of natural, home birth followed-up by experienced midwives is still associated with lack of economic resources and difficulty of access to health services ${ }^{\mathbf{3 8}}$. However, recent initiatives by the Ministry of Health have been guiding actions to humanize childbirth. In this sense, achievements such as the creation of the Normal Childbirth Centers (1999)39, the National Program for the Humanization of Prenatal Care and Childbirth (2000) ${ }^{40}$ and the Rede Cegonha (Stork Network, 2011) ${ }^{\mathbf{4 1}}$ consolidate the model of obstetric assistance for the humanization of childbirth in the country ${ }^{\mathbf{3 8}}$. Recent literature on the subject points out that highly educated women from the South and Southeast regions are seeking private services for planned home birth. In this context, doulas and obstetric nurses are professionals qualified to perform home monitoring ${ }^{38}$.

In the current moment of women's health, when there is an advocacy of humanized and home birth, and at the same time there is a frailty of public health services in isolated communities, it is essential for health managers in Amazonian municipalities to consolidate actions aimed at training new midwives, as well as updating and guiding professional midwives.

Regarding gestational age, $86 \%(n=24)$ of births occurred between the 37th and 41st weeks of gestation. This index is below the one calculated for the urban region of the municipality of Tefé (AM), which was of $93.07 \%$, for the period from 2006 to $2012^{31}$. In this context, the high rate of preterm births is reason to worry and points to the urgency of improving the protocols for prenatal care, considering the social and cultural specificities of isolated rural communities, especially Vila Sião, Alvarães (AM).

These women had a high fertility ratio, ranging from two $(n=8 ; 28.6 \%)$ to more than five completed pregnancies ( $\mathrm{n}=10 ; 35.7 \%$ ). Regarding the parameter of pregnancy loss, $53.6 \%(n=15)$ stated that they had already undergone two or more abortions. Pregnancy interruptions were attributed to eclampsia, household accidents and illnesses in general. These data emphasize the importance of prenatal care for promoting the health of the pregnant woman and the baby. In fact, the performance of consultations and supplementary exams as pregnancy evolves is essential to protect and prevent against adverse events, 
allowing the identification and clinical handling of appropriate interventions regarding potential obstetric risk factors ${ }^{\mathbf{4 2 , 4 3}}$.

The gestational indicators investigated in this study indicate that the risk factors of women from the Vila Sião community, Alvarães (AM), cannot be disregarded. The occurrence of premature deliveries, the reports of fetal loss or stillbirth and the recognition of maternal diseases (eclampsia) are controllable risk predictors. However, the concern about the well-being of pregnant/parturient women and their offspring requires consolidation. Bringing the health services to the hinterland is essential for care and specialized medical assistance to reach riverside and isolated communities. After all, a significant part of the population of the state of Amazonas resides in communities, settlements and indigenous villages and is therefore in a situation of geographic isolation.

Table 4. Gestation indicators included in the analyses of the reproductive profile of adult women resident in Vila Sião, Alvarães (AM), 2019

\begin{tabular}{lrr}
\hline Gestational indicators & Number of people & Percentual (\%) \\
\hline Type of delivery & & \\
\hline Vaginal & $27 \%$ \\
Cesarean section & 9 & $7 \%$ \\
Both & & $32 \%$ \\
\hline Gestational age & 24 & $86 \%$ \\
\hline Carried to term & 4 & $14 \%$ \\
Before term & & $28.6 \%$ \\
\hline Parity & 8 & $35.7 \%$ \\
\hline 2 children & 10 & $35.7 \%$ \\
\hline and 4 children & 10 & \\
$\geq 5$ children & & $53.6 \%$ \\
\hline History of gestational loss & 15 & $46.4 \%$ \\
\hline Yes & 13 & \\
\hline
\end{tabular}

Source: Own elaboration.

A limitation to the research that must be pointed out is the scarcity of qualified scientific studies about neglected population groups such as the riverside populations of the state of Amazonas. Likewise, an atypical environment - with dense tropical forest, immense rivers and torrential rains - is something that restricts the acquisition of scientific information by researchers. The lack of information frustrates the performance of more comprehensive comparative analyses regarding the health and reproduction indicators of women in a situation of geographic isolation. In this regard, the development of studies in the Amazonian environment must be supported not only by financial resources but also by additional efforts when compared to studies developed in urban areas. In this way, it is hoped that the results of the present study can contribute to the development of future investigations among riverside peoples located in the state of Amazonas and guide aspects that 
may allow the articulation of public policies for these peoples.

\section{Conclusions}

The results of the present study indicate that the reproductive behavior of women from Vila Sião, Alvarães (AM), occurs under risky conditions. Social and gestational indicators show a pattern of reproduction characterized by early pregnancy, high fertility rate and pregnancy losses. Such a reproduction profile implies risky pregnancies to the riverside women themselves and their children, since, in most cases, they do not meet the minimum interpregnancy period of 18 months established by the parameters of modern medicine. Almost every birth is performed without prenatal care and only in a few cases there is a degree of reproduction planning by the women.

It is also stressed that primary care based on the medicalizing and hospital-centered model is a factor that keeps riverside and geographically isolated populations away from healthcare. However, the creation of programs for humanized prenatal care and family planning - as well as investment in training, qualification and updating of specialized health professionals - is something capable to guarantee quality service to riverside women. In fact, family monitoring and planning programs should guide humanized care and consider the cultural values and the popular knowledge of riverside and isolated communities.

Finally, one must emphasize the need to improve and expand prenatal care services, to raise awareness on the risks of eclampsia for maternal health, and to create reproductive health programs that may recognize the social and cultural conditions of the isolated communities existing in the state of Amazonas.

\section{Collaborators}

Cabral I (0000-0002-0328-4745)* contributed substantially to the conceiving, planning, analysis and interpretation of data; contributed significantly to the elaboration of the draft and the critical review of the content; and participated in the approval of the final version of the manuscript. Cella W (00000002-8107-3062)* contributed substantially to the conceiving and planning of the study; contributed significantly to the critical review of the content; and took part in the approval of the final version of the manuscript. Freitas SR (0000-0003-2987-7837)* contributed substantially to the analysis and interpretation of data; contributed significantly to the elaboration of the draft and the critical review of the content; and participated in the approval of the final version of the manuscript. 


\section{References}

1. Wong LLR, Morell MGG, Carvalho RL. Notas sobre o comportamento reprodutivo da população autodeclarada indígena - Censos Demográficos 1991 e 2000. Rev. Bras. Estudos Pop. 2009; 26(1):61-75.

2. Horta CJ, Carvalho JAM, Nogueira OJO. Evolução do Comportamento Reprodutivo da Mulher Brasileira 1991-2000. Cálculo da Taxa de Fecundidade Total em Nível Municipal. Rev. Bras. Estudos Pop. 2005; 22(1):131-140.

3. Fundação Sistema Estadual de Análise de Dados Natalidade e Fecundidade em São Paulo. O Risco da Interpretação Equivocada dos Dados. São Paulo: SP Demográfico; 2004.

4. Dias CS. Diferenciais no Comportamento Reprodutivo das Mulheres Brasileiras: Uma Análise a partir dos Grupos Ocupacionais. Rev. Ciênc. Soc. 2008; 53(1):233-265.

5. Alves JED. Questões Demográficas: Fecundidade e Gênero. Rio de Janeiro: Escola Nacional de Ciências Estatísticas; 2004.

6. Moura EAF. Comportamento reprodutivo das mulheres ribeirinhas do Amanã. Uakari. 2005; 1(1):31-39.

7. Gupta N, Leite IC. Tendências e determinantes entre adolescentes do Nordeste do Brasil. Persp. Inter. Plan. Fam. 2001; 45(esp):24-29.

8. Villela TF, Vieira EM, Gonçalves TC, et al. Declaração de nascidos vivos no município de Volta Redonda, RJ: perfil da gestante adolescente. Cad. UniFOA. 2018; 6(2):59.

9. Rodrigues ARS, Barros WM, Soares PDFL. Reincidência da gravidez na adolescência: percepções das adolescentes. Enf. Foco. 2016; 7(3/4):66-70.

10. Ruzany MH, Moura EAF, Meirelles ZV. Adolescentes e jovens de populações ribeirinhas na Amazônia - Brasil. Rio de Janeiro: Visão Social; 2012.
11. Oliveira RS. Os "filhos da mãe" no Médio Solimões. In: $13^{\circ}$ Anais do Seminário Internacional Fazendo Gênero; 2013 set 16-20; Florianópolis. Florianópolis: UFSC; 2012.

12. Gama ASM, Fernandes TG, Parente RCP, et al. Inquérito de saúde em comunidades ribeirinhas do Amazonas, Brasil. Cad. Saúde Pública. 2018; 34(2):17-22.

13. Lima DM. Ribeirinhos, Pescadores e a Construção da Sustentabilidade nas Várzeas dos Rios Amazonas e Solimões. Boletim Rede Amazônia. 2004; 3(1):57-66.

14. Loureiro JJ. A Amazônia no século XXI: novas formas de desenvolvimento. São Paulo: Editora Empório do Livro; 2009.

15. Cabral IKS, Cella W, Freitas SRS. Reproductive behavior of women from a rural community in Tefé, Amazonas, Brazil. Braz. J. Biol. Sciences. 2019; 6(14):497504.

16. Bôas LMS, Oliveira DC. A saúde das comunidades ribeirinhas da região Norte brasileira: Revisão sistemática da literatura. Invest. Qualitat. Saúde. 2016; 2(3):62-71.

17. Franco EC, Santo CE, Arakwa AM, et al. Promoção da população ribeirinha da região Amazônica: Relato de experiência. Rev. CEFAC. 2015; 17(5):1521-1530.

18. Costa MCO. Indicadores materno-infantis na adolescência e juventude: sociodemográfico, pré-natal, parto e nascidos-vivos. J. Pediat. 2001; 77(3):235-242.

19. Mascarenhas MDM, Rodrigues MTP, Monte NF. Caracterização dos partos e dos nascidos vivos em Piripiri, Piauí, Brasil. Rev. Bras. Saúde Mat. Infant. 2006; 6(2):175-181.

20. Instituto Chico Mendes de Conservação da Biodiversidade. Plano de manejo da Floresta Nacional de Tefé: diagnósticos. Brasília, DF: ICMBIO; 2014.

21. Brianezi A. Floresta Nacional de Tefé: encontros e 
desencontros das políticas ambiental e agrária na Amazônia. Rev. IDEAS. 2008; 2(2):256-283.

22. Oliveira MG, Suertegaray DMA, Pires CLZ. Mapeamento participativo e uso do SIG: FLONA de Tefé-AM. In: Anais do $16^{\circ}$ Simpósio Brasileiro de Sensoriamento Remoto; 2013 abr 18; Foz do Iguaçu. Foz do Iguaçu: INPE; 2013.

23. Piperata BA, Spence JE, Dagloria P, et al. The nutrition transition in Amazonia: rapid economic change and its impact on growth and development in ribeirinhos. Am. J. Physiol. Anthr. 2011; 1(46):1-13.

24. Anunciação-Lima CM, Alcântara KD, Cerqueira JML, et al. Iniciação sexual, gestação, parto e puerpério em comunidades indígenas do Brasil: uma breve revisão integrativa. Rev. Saúde Púb. 2018; 1(1):86-101.

25. Abramovay M, Castro MG, Silva LB. Juventude e sexualidade. Brasília, DF: UNESCO; 2004.

26. Ricci AP, Sene AG, Souza BLB, et al. Infecções sexualmente transmissíveis na gestação: educação em saúde como estratégia de prevenção na atenção básica/ Sexually transmitted infections during pregnancy: health education as a prevention strategy in primary care. Braz. J. Health Rev. 2019; 2(1):565-570.

27. Silva LR, Silva RF. Conhecimento, atitudes e crenças de mulheres ribeirinhas frente à concepção e contracepção. Rev. Enfer. 2009; 3(4):72-80.

28. Ribeiro JELS. Guia de identificação das plantas vasculares de uma floresta de terra firme na AM central. 19. ed. Manaus: Midas Printing; 1999.

29. Silva RJB, Oliveira APS, Silva RLF. Crenças populares: Atribuições místicas e medicinais às plantas na baixada cuiabana, Mato Grosso, Brasil. Biodivers. 2018; 17(1):61.

30. Vásquez SPF, Mendonça MS, Noda SN. Etnobotânica de plantas medicinais em comunidades ribeirinhas do Município de Manacapuru, Amazonas, Brasil. Acta Amaz. 2014; 44(4):457-472.
31. Cella W, Marinho KO. Delineamento epidemiológico dos nascidos vivos em Tefé, Amazonas, no período de 2006 a 2012. Arq. Ciênc. Saúde UNIPAR. 2017; 21(2):99-104.

32. Cabral ZAF. Manual de Genecologia infanto juvenil. São Paulo: Federação brasileira de ginecologia e obstetrícia; 2014.

33. Ruzany MH, Andrade CLT, Meireles ZV, et al. Desinformação e vulnerabilidades com relação à sexualidade dos adolescentes e jovens da Reserva de Mamirauá, Amazonas - Brasil. Adolesc. Saúde. 2010; 7(2):41-49.

34. Oliveira MJP, Lanza LB. Educação em saúde: doenças sexualmente transmissíveis e gravidez na adolescência. Rev. Facul. Ciências Méd Sorocaba. 2018; 20(3):138-141

35. Franze AMAK, Benedet DCF, Wall ML, et al. Planejamento reprodutivo nas orientações em saúde: revisão integrativa. REFACS. 2019; 7(3):366-377.

36. Malta DC, Machado ÍE, Felisbino-Mendes MS, et al. Uso de substâncias psicoativas em adolescentes brasileiros e fatores associados: Pesquisa Nacional de Saúde dos Escolares, 2015. Rev. Bras. Epidemiol. 2018; (21):e180004.

37. Duarte ES, Pamplona TQ, Rodrigues AL. A gravidez na adolescência e suas consequências biopsicossociais. DeCiência FOCO. 2018; 2(1):45-52.

38. Castro CM. Os sentidos do parto domiciliar planejado para mulheres do município de São Paulo, São Paulo. Cad. Saúde Col. 2015; 23(1):69-75.

39. Campos SEV, Lana FCF. Resultados da assistência ao parto no Centro de Parto Normal Dr. David Capistrano da Costa Filho em Belo Horizonte, Minas Gerais, Brasil. Cad. Saúde Pública. 2007; 23(6):1349-1359.

40. Gligio MRP, França E, Lamouner JA. Avaliação da qualidade da assistência ao parto normal. Rev. Bras. Ginecol. Obst. 2011; 33(10):297-304. 
41. Brasil. Ministério da Saúde. Departamento de Ações Programáticas Estratégicas. Gestação de alto risco: manual técnico. Brasília, DF: Ministério da Saúde; 2012.

42. Basso CG, Neves ET, Silveira A. Associação entre realização de pré-natal e morbidade neonatal. Contex. Enf. 2012; 21(2):76-269.
43. Brasil. Ministério da Saúde. Pré-natal e puerpério: atenção qualificada e humanizada: manual técnico. Brasília, DF: Ministério da Saúde; 2006.

Received on $12 / 09 / 2019$

Approved on 09/18/2020

Conflict of interests: non-existent

Financial support: Fundação de Amparo à Pesquisa do Estado do Amazonas (Fapeam). Edital Paic/Fapeam/UEA no 021/2018 and Sisproj no 14404 